\title{
High Lending Rates in Indonesia: Inflation Rates and Bank Inefficiencies
}

\author{
Ari Christianti
}

\author{
Duta Wacana Christian University, Address: Jl. Dr. Wahidin S. No.05-25, Yogyakarta 5524, Indonesia
}

\begin{abstract}
Inefficient banking systems will affect the Indonesian economy resulting in a high lending rate structure which impacts the cost of capital in real sectors. This study aims to determine if the high lending rates in Indonesia are caused by the high inflation rate and bank inefficiencies. Using monthly panel data analysis from four categories of commercial banking in Indonesia for the period January 2009December 2017, the results of the study show that operating expenses operating income (OEOI) and net interest margin (NIM) factors, as a measure of efficiency, have a positive impact on loan interest rates for working capital loans, investment loans and consumer loans. Furthermore, inflation rate has a positive effect on loan interest rates for working capital and investment loans only. However, this contrasts with consumer credit where the inflation rate has a negative effect on consumer credit rates. This might be attributed to the fact that interest rates for consumer credit consider default risk factors and high demand rather than inflation factors.
\end{abstract}

Keywords - Lending rates, working capital loans, investment loans, consumer loans, inflation rate and efficiency.

\section{Introduction}

Efficiency in the banking industry in Indonesia has recently become the concern of many government parties and policy makers, because bank operating inefficiencies will result in the economy having a high interest rate structure and a high cost of capital in the real sector.

DOI: $10.18421 /$ SAR33-02

https://doi.org/10.18421/SAR33-02

Corresponding author: Ari Christianti, Duta Wacana Christian University, Address: Jl. Dr. Wahidin S. No.05-25, Yogyakarta 5524, Indonesia Email: ari@staff.ukdw.ac.id

Received: 23 July 2020.

Revised: 02 September 2020.

Accepted: 08 September 2020.

Published: 29 September 2020.

(cc)BY-NC-ND(C) 2020 Ari Christianti; published by UIKTEN. This work is licensed under the Creative Commons Attribution-NonCommercial-NoDerivs 3.0 License.

The article is published with Open Access at www.sarjournal.com
OEOI and NIM are the measurements used by the Authority of Financial Services (AFS) (OJK-Otoritas Jasa Keuangan) to measure bank efficiency in Indonesia. Citing the latest data from the Federal Reserve Bank of State Louis (2016), the NIM of banks in Singapore at of the end of 2016 was only $1.39 \%$, Malaysia $1.92 \%$, Thailand $2.93 \%$, Vietnam $2.99 \%$, Philippines $3.31 \%$, and Indonesia $6.39 \%$. This means that the NIMs of banks in Indonesia are relatively high compared to other ASEAN countries.

Apart from bank inefficiencies, the inflation rate is also a cause of high lending rates in Indonesia. This means, if the inflation rate in Indonesia is high, it is difficult for the banking industry to charge a low interest rate on credit, because of the inflation that resulted in banks experiencing losses due to the decreasing value of bank loans. As a result, banks are willing to provide loans only if the loan interest charged covers the rate of inflation, so the nominal interest rate becomes high as indicated by the Fisher effect (nominal interest rate $=$ real interest rate + expected rate of inflation) [6].

The following Table shows the comparison of inflation rates, loan interest rates and deposit rates of ASEAN countries:

Table 1. Inflation Rate, Credit Rate and Deposit Rate of ASEAN Countries

\begin{tabular}{|c|l|c|c|c|}
\hline No. & \multicolumn{1}{|c|}{ Country } & $\begin{array}{c}\text { Inflation } \\
\text { Rate } \\
(\boldsymbol{\%})\end{array}$ & $\begin{array}{c}\text { Credit } \\
\text { Rate } \\
(\boldsymbol{\%})\end{array}$ & $\begin{array}{c}\text { Deposit } \\
\text { Rate } \\
(\boldsymbol{\%})\end{array}$ \\
\hline 1 & Singapore & 4.6 & 1.85 & 0.75 \\
\hline 2 & Malaysia & 3.3 & 4.75 & 4.05 \\
\hline 3 & Philippines & 5.3 & 5.50 & 2.50 \\
\hline 4 & Vietnam & 18.9 & 6.49 & 7.40 \\
\hline 5 & Brunei & 2.0 & 7.50 & 0.75 \\
\hline 6 & Indonesia & 5.7 & 10.25 & 5.70 \\
\hline 7 & Thailand & 4.1 & 12.00 & 2.80 \\
\hline
\end{tabular}

Source: https://asean.deposits.org (February-June 2018)

Based on Table 1 above, the credit interest rates of Indonesia and Thailand are higher than other ASEAN countries. Singapore has the lowest credit interest rates of all the ASEAN countries with an interest rate of $1.85 \%$.

The high lending rates in Indonesia compared to other ASEAN countries will have an impact on the cost of capital issued by the banking industry to 
obtain funds. Moreover, in 2020, Indonesia will be subject to the AEC banking regulations, so the banking industry in Indonesia has to able to compete with ASEAN countries, especially in terms of lending rates. Therefore, the Indonesian government, through the AFS, issued a regulation concerning incentives for banks that experience increased efficiency. This regulation aims to encourage banking efficiency to reach target credit interest rates of less than $10 \%$.

In addition, Bank Indonesia Circular Letter Number 8/15/DPNP (Direktorat Penelitian dan Pengaturan Perbankan-Directorate of Banking Research and Regulation) concerning the opening of a network of commercial bank offices based on core capital was issued on March 8, 2013. There are three indicators that were taken into consideration by Bank of Indonesia in passing plans for opening branches. Namely, the availability of core capital allocations according to the location and type of bank offices (theoretical capital), the portion of micro, small and medium enterprises (MSMEs) loans or small micro enterprises (SMEs) and efficiency through OEOI and NIM.

Based on this explanation, it can be concluded that the high credit interest rate imposed by the banking industry in Indonesia is likely due to the high level of inflation and the inefficient banking in carrying out their intermediary role. This is interesting, given the many statements and data about this matter, but it has not been empirically proven whether the high lending rates in Indonesia are caused by high levels of inflation and bank inefficiencies, making it difficult for banks to reduce lending rates below $10 \%$.

This study will compare efficiency and inflation rate to the credit interest rate imposed by commercial banks in Indonesia. The credit interest rates used in this study are based on the purpose or type of use which are divided into three categories: working capital loans, investment loans, and consumer loans.

\section{Literature Review}

A study on bank lending rates by [9] stated that factors that influence the determination of interest rates consist of demand for credit and deposits, operational costs, credit risk, interest rate volatility, channel interest rates (interest rate channel), and bank credit channel (bank lending channel). Research by [16] states there are three factors that influence the determination of interest rates: (1) bank-specific factors such as operating and administrative costs, non-performing loans (NPL), return on assets (ROA), balance sheet structure, non-interest income, bank size, and bank liquidity, (2) specific factors from the banking sector or industry such as competition or market concentration, and regulation, and (3) economic indicators such as real gross domestic product (GDP) and inflation rate. [13] stated the main bank specific determinant of interest rates are deposit market share, liquidity level and operating cost.

Interest rate spread (IRS) is one measure of bank efficiency. Interest rate spread is the margin between loan interest rates and deposit rates. Financial systems in developing countries show a higher IRS compared to developed countries ([12]; [3]; [14]). The high IRS in developing countries is due to several factors including high operational costs, financial repression (i.e., interest rates are determined by financial authorities), lack of competition, market strength and high inflation rates ([15]; [2]; [4]; [5]). [10] stated that credit risk, bank concentration, efficiency, and inflation expectations influenced the margin of bank interest rates.

Research on determining interest rates in Indonesia conducted by [11] examined the factors that determine NIM by using internal and external factors. The results showed that internal factors consist of growth in bank assets, profitability, efficiency, capital adequacy ratio (CAR), liquidity and risk, while external factors included the inflation rate's effect on the interest margin. Based on the above research, this study will empirically examine the effect of efficiency and inflation rates on credit interest rates.

\section{Research Methods}

Although there are many statements and research on bank efficiency and inflation that could explain high lending rates in Indonesia, there are no empirical studies that test the effect of efficiency and inflation rate on credit interest rates. For this reason, empirical evidence is needed to test this in Indonesia. The subjects of analysis used in this study are commercial banks observed over the nine-year period 2009-2017 (monthly observations).

Commercial banks are banks that carry out conventional business activities which provide services in payment traffic. The commercial banks used in this study consist of four groups: state-owned banks (BUMN-Bank Umum Milik Negara), regional development banks (BPD-Bank Pembangunan Daerah), national private commercial banks (BUSNBank Umum Swasta Nasional), and foreign-mixed banks. State-owned banks are banks whose shares (including partial ownership) are owned by the Government of the Republic of Indonesia. Regional development banks are owned by the provincial government (including partial ownership). National private commercial banks are owned by the national private sector (including partial ownership), which is divided into foreign exchange banks and non-foreign 
exchange banks based on foreign exchange transactions. Finally, foreign-mixed banks are banks where a branch exists abroad. On the other hand, foreign or foreign government mixed banks are banks whose shares are owned by foreign parties and national private parties.

The data used in this study is secondary data taken from the publication of the Indonesia Banking Statistics (SPI-Statistik Perbankan Indonesia) January 2009 to December 2017. In addition, monthly inflation rate data was obtained from the Bank of Indonesia website, while the commercial bank monthly credit interest rate data was obtained from the website of the Central Bureau of Statistics.

\section{Model Estimations}

This study examines the positive effect of bank operational efficiency on credit interest rates in the form of panel regression where a regression between loan interest rates (working capital loans, investment loans and consumer loans) was carried out as the dependent variable with inflation, OEOI, and NIM as independent variables. The following regression equations were estimated:

Equation 1:

$\mathrm{WC}_{\mathrm{it}}=\alpha_{\mathrm{i}}+\beta 1 *$ Inflation $_{\mathrm{it}}+\beta 2 * \mathrm{OEOI}_{\mathrm{it}}+\beta 3 * \mathrm{NIM}_{\mathrm{it}}+\mathrm{e}_{\mathrm{it}}$

Equation 2:

Invest $_{\mathrm{it}}=\alpha_{\mathrm{i}}+\beta 1 *$ Inflation $_{\mathrm{it}}+\beta 2 * \mathrm{OEOI}_{\mathrm{it}}+\beta 3 * \mathrm{NIM}_{\mathrm{it}}+\mathrm{e}_{\mathrm{it}}$

Equation 3:

Consumer $_{i t}=\alpha_{\mathrm{i}}+\beta 1 *$ inflation $_{\mathrm{it}}+\beta 2 * \mathrm{OEOI}_{\mathrm{it}}+\beta 3 * \mathrm{NIM}_{\mathrm{it}}+\mathrm{e}_{\mathrm{it}}$

This study uses panel data and an analysis of the fixed effect model (FEM) which considers interception between different variables. In addition, to eliminate heteroscedastic problems in the model, the FEM estimation uses a cross-section weighting procedure.

\section{Results}

This study empirically examined the effect of inflation and banking efficiency on determining loan interest rates based on bank groups. The following Table is a descriptive analysis of the variables in this research:

Table 2. Descriptive Analysis

\begin{tabular}{|c|c|c|c|c|c|c|}
\hline & 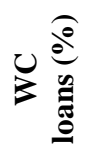 & 苞 & 咆氙 & 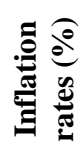 & 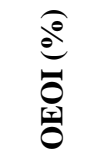 & $\frac{\widehat{\theta}}{z}$ \\
\hline Mean & 12.10 & 11.72 & 17.58 & 5.20 & 81.56 & 5.72 \\
\hline Med. & 12.42 & 11.84 & 13.64 & 4.58 & 80.60 & 5.96 \\
\hline Max. & 15.99 & 14.95 & 35.96 & 9.17 & 173.89 & 9.36 \\
\hline Min. & 7.83 & 8.84 & 11.14 & 2.41 & 64.26 & 2.09 \\
\hline
\end{tabular}

Based on Table 2, in general, the credit interest rate is in the range of two digits with the highest average credit interest rate presenting for consumer loans. The consumer loan interest rate reaches a maximum value of $35.96 \%$. Consumer loans have the highest risk of default plus the demand for these loans are superior compared to the demand for working capital loans and investment loans. The default risk for consumer loans is higher than others because there are many types of consumer loans including unsecured loans, those that do not require collateral.

The average inflation rate during the study period was $5.19 \%$, the highest inflation rate was $9.17 \%$, and the lowest inflation rate was $2.41 \%$. The average inflation rate in Indonesia was relatively high at $5.19 \%$. This is higher than the bank central target which is required to be in the range of $3 \%-4 \%$. The high inflation rate makes it difficult for the banking industry to impose the low interest rates expected by the government. Inflation causes banks to suffer losses because of the falling value of bank loans. As a result, the real rate charged by banks is high.

Furthermore, the OEOI ratio, one of the indicators of efficiency in the banking industry in Indonesia, reached an average of $81.56 \%$ during the study period. This figure shows that OEOI, on average, is at a safe limit. Banks with OEOI above 85 percent will be under the supervision of the AFS. Meanwhile, banks that have an OEOI ratio below $85 \%$ are eligible to get discounts on the core capital allocation. For example, banks with core capital 5-30 trillion which have both NIM ratio below $4.5 \%$ and OEOI ratio below $80 \%$ get discounts $50 \%$ on the core capital allocation. However, based on banking groups there are still banks that have a very high OEOI ratio (173.89\%). This OEOI ratio of $173.89 \%$ was earned by the state-owned banks group in January 2011. This was a result of increased depreciation and amortization. Several state-own banks use the double-declining principle in recording amortization costs, resulting in accelerated depreciation. The lowest OEOI ratio of $64.26 \%$ was obtained by the regional development banks group. Ideally, a good OEOI is in the range of $60-70 \%$.

Finally, the NIM ratio also measures banking operational efficiency. The NIM ratio average is $5.72 \%$ with the highest NIM equalling $9.36 \%$ and the lowest NIM equalling $2.09 \%$. The ratio of NIM that would secure incentives is a NIM ratio lower than $4.5 \%$. Based on the average NIM ratio $(5.72 \%)$, commercial banks have a NIM above 5\% (71.53\%). Therefore, banks with a NIM ratio above 5\% are charging high interest rates.

In this section, the results of the analysis on the effect of inflation, OEOI and NIM on interest rate loans (based on working capital loans, investment loans and consumer loans) is explained. The following are the results of the estimation and discussion relating to the research: 
Table 3. Data Results

\begin{tabular}{|l|c|c|c|}
\hline \multicolumn{1}{|c|}{ Variable } & WC & Invest & Consumer \\
\hline & & & \\
Inflation rates & $0.132450^{* * *}$ & $0.107701^{* * *}$ & $0.03803^{* *}$ \\
OEOI & $0.041136^{* * *}$ & $0.032006^{* * *}$ & $0.026612^{* * *}$ \\
NIM & $0.227523^{* * *}$ & $0.299435^{* * *}$ & $0.422884 * *$ \\
\hline & & & \\
Fixed Effect & & & \\
(Cross) & & & \\
State-Owned & & & \\
Banks & & & \\
Regional & 0.153467 & -0.702040 & -4.769593 \\
Development & 1.182360 & 0.272083 & -4.463734 \\
Banks & & & -4.042175 \\
National & 0.539878 & 0.755298 & \\
Private & & & 13.27550 \\
Commercial & -1.875704 & -0.325341 & \\
Banks & & & \\
Foreign- & & & \\
Mixed Banks & & & \\
& & & \\
\hline Weighted & & & \\
Statistics & & & \\
R-squared & 0.618469 & 0.527015 & \\
Adjusted R- & 0.613082 & 0.520338 & \\
squared & & & \\
& & & \\
\hline
\end{tabular}

Notes: $* *$ and $* * *$ denote significance at $5 \%$ and $1 \%$ levels, respectively

\subsection{The Relationship between Inflation and Efficiency towards Working Capital-Type Credit Rates}

Based on the estimation results in Table 3, the independent variables inflation and efficiency (OEOI and NIM) have significant influence on the interest rates of working capital loans. This is indicated by a $\mathrm{p}$-value, for the three independent variables, that is smaller than 0.01 .

The inflation variable has a positive and significant effect on interest rates of working capital loans. This result is in accordance with the interest rate theory proposed by [7]. The theory pre states that nominal interest rate $=$ real interest rate + expected rate of inflation. This means, if the inflation rate is high, then the banking industry will charge a high interest rate because it does not want to lose the value by which bank loans will decrease. As a result, the real rate charged by banks is higher.

The following is a graph that explains the relationship between inflation and interest rates on working capital loans.

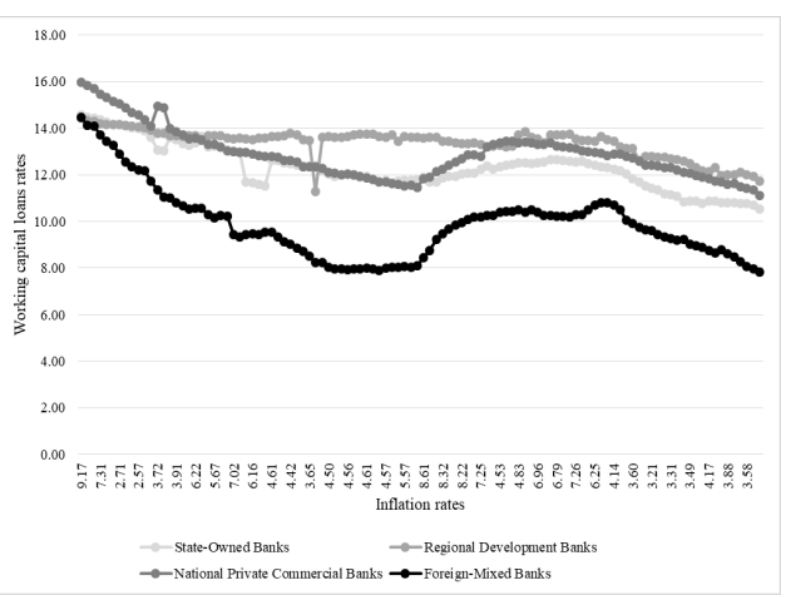

Graph 1. The Relationship between Inflation towards Working Capital-Type Credit Rates

Based on Graph 1, there is a tendency for the interest rates on working capital loans to rise when inflation rates rise and vice versa.

The OEOI variable shows a positive and significant influence on loan interest rates for working capital loans. This result shows that the higher the OEOI ratio, the lower the efficiency of banking operations which increases interest rates on credit. The results of this study support the research of [12], and [3] that states that the inefficiency of banks in performing intermediary functions causes banks to transfer inefficiencies by imposing high interest rates. The results of the study show that the NIM variable also has a significant positive effect on the lending rate of working capital loans. IRS is one measure of bank efficiency. Interest rate spread is the margin between loan interest rates and deposit rates, or NIM, in Indonesia. The higher NIM indicates that commercial banks are not efficient because they are still too high in charging interest rates. In addition, the output results presented in the Table 3 above show the Regional Development Banks bank group with a change in average interest rate on working capital loans above average compared to loans of commercial banks as a whole.

Based on the four groups of banks in this study, the banking groups with the highest average change in loan interest rates consecutively (from smallest to largest change) are regional development banks, national private commercial banks, state-owned banks, and foreign-mixed banks. The regional development banks have the largest change in lending rates for working capital loans (11.28\% $14.44 \%)$. The average interest rate on working capital loans during the study period was $13.40 \%$. This is different from foreign-mixed banks which have the lowest average change in interest rates $(7.83 \%-14.46 \%)$ with an average loan interest rate for working capital loans during the study period of $9.81 \%$. This shows that foreign-mixed banks in Indonesia can offer lower interest rates compared to other bank groups, as in the period of 2017 when the average loan interest rate on working capital loans was only $8.52 \%$. 


\subsection{The Relationship between Inflation and Efficiency towards Investment-Type Credit Rates}

The results for the estimation of investment capital loans are the same as for working capital loan rates: The independent variables of inflation, OEOI, and NIM have a significant positive effect on interest rates for investment loans. This means the three independent variables have a relationship in line with the theory proposed.

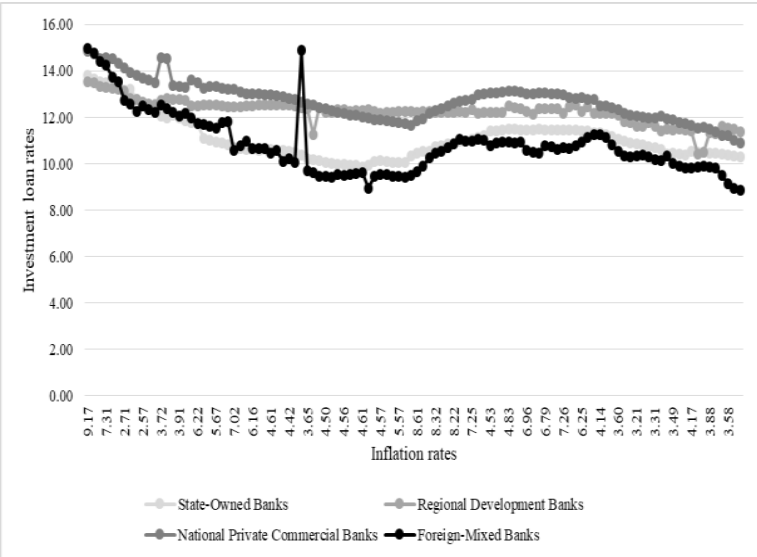

Graph 2. The Relationship between Inflation towards Investment-Type Credit Rates

Based on Graph 2, there is a tendency when inflation rises, for the interest rates of working capital loans and investment loans to rise and vice versa.

Based on the four groups of banks sampled in this study, the group of banks with the largest change in loan interest rates from investment loans from commercial banks is (from highest to lowest) national private commercial banks, regional development banks, state-owned banks, and foreignmixed banks. National private commercial banks have the highest average change in loan interest rates, since the average loan interest rate charged by national private commercial banks ranges from $10.89 \%-14.83 \%$ with the average loan interest rate for investment types during the study period at $12.71 \%$. This contrasts with foreign-mixed banks, which have the lowest average change in investment loan interest rate (below the average loan interest rate for commercial banks as a whole). The average interest rate on these loans ranges from $8.84 \%$ $14.95 \%$ with an average loan interest rate during the study period of $10.82 \%$. It could be concluded that foreign and mixed banks in Indonesia offer the lowest interest rates compared to other bank groups. This means that foreign and mixed banks contribute to the national economy by charging a lower interest rate to the productive sector. It is expected that foreign banks will play larger roles in the economy in the future by providing productive loans, especially to MSMEs.

\subsection{The Relationship between Inflation and Efficiency towards Consumer-Type Credit Rates}

Finally, the estimation of consumer-type loans shows that the independent variables (inflation, OEOI, and NIM) significantly influence consumer credit rates. However, unlike the previous estimation results, the inflation variable in this estimation shows a negative and significant influence on consumertype loan interest rates. The following figure illustrates the relationship between inflation and interest rates on consumer loans:

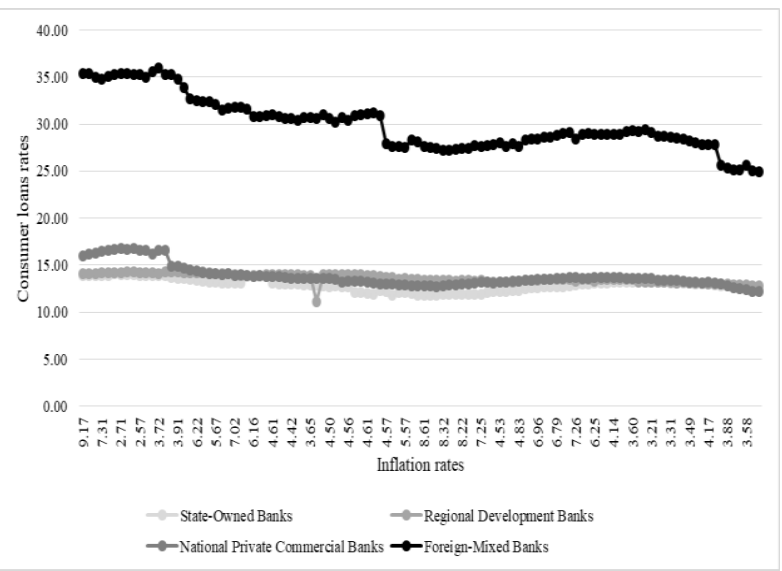

Graph 3. The Relationship between Inflation and Efficiency towards Consumer-Type Credit Rates

Graph 3 shows that foreign-mixed banks charge highest interest rates compared to other bank groups. In general, there is a tendency for consumer credit interest rates to be stable and not follow inflation movements. This means that when inflation falls consumer credit interest rates tend not to fall, but to rise with a stable movement.

This could be because the interest rate for consumer loans is determined by the risk of default and increasing demand in line with ([1]; [9]; [8]) . Default risk for consumer loans is higher than other types of loans because most consumer loans have minimal or no guarantees, such as unsecured loans. This causes the bank to bear a higher risk, so it imposes higher loan interest rates. In addition, the demand for these loans is high because it is easier to process consumer credit applications than other types of credit applications.

Based on the four banking groups, the group of banks with the highest average change in lending rates for consumers is foreign-mixed bank groups with interest rates above average lending rates for commercial banks. Foreign-mixed banks have consumer interest rates ranging from $24.90 \%$ $35.96 \%$ with the average rate reaching $29.99 \%$. This shows that foreign-mixed banks in Indonesia offer the highest interest rate compared to other bank groups, as evidenced in the period of 2017 where the 
average loan interest rate for consumers reached $26.38 \%$. Consumer loan interest rates imposed by foreign-mixed banks indirectly replace low interest rates for working capital loans and investment loans. This means that the role of foreign- mixed banks in the economy is not optimal.

\section{Conclusions}

Based on the results, it could be concluded that bank inefficiencies as measured by OEOI and NIM have a positive influence on loan interest rates (working capital loans, investment loans, and consumer loans). Bank inefficiencies indicated by high OEOI and NIM ratios cause banks to transfer inefficiencies by charging higher interest rates ([12]; [3]).

The inflation rate has a positive influence on credit interest rates for working capital loans and investment loans. This result supports [7] Fisher effect theory which states that nominal interest rates are obtained from real interest rates plus the expected rate of inflation. If the inflation rate is high, then the banking industry will charge a high interest rate because it does not want to lose money on the decreasing value of bank loans. As a result, the real rate charged by banks is high. However, the inflation rate has a negative and significant effect on consumer lending rates. Determining consumer credit interest rates is more complicated because of default risk factors and relatively high demand ([1]; [9]; [8]) such as in the case of unsecured loans.

Considering working capital loans, regional development banks have the highest average change in lending rates compared to other bank groups. Foreign-mixed banks had the lowest average change in working capital loan interest rates (below the average lending rate for commercial banks) compared to other bank groups.

When considering investment loans, national private commercial banks have the highest average change in loan interest rates compared to other bank groups. Like working capital loans, foreign-mixed banks have the lowest average change in investment credit interest rates (below the average investment interest rate for commercial banks) compared to other bank groups. For consumer credit, this group of banks has the highest average change in loan interest rates compared to other bank groups.

The finding that even though the regulator has applied the rules concerning the opening of a network of commercial bank offices based on efficiencies, there are still many banks which have higher both OEOI ratio and NIM ratio than expected. So, for future research we can hopefully study how government incentives are impacting bank efficiency.

\section{References}

[1]. Angbazo, L. (1997). Commercial bank net interest margins, default risk, interest-rate risk, and offbalance sheet banking. Journal of Banking \& Finance, 21(1), 55-87.

[2]. Aryeetey, E., Hettige, H., Nissanke, M., \& Steel, W. (1997). Financial market fragmentation and reforms in Ghana, Malawi, Nigeria, and Tanzania. The World Bank Economic Review, 11(2), 195-218.

[3]. Barajas, A., Steiner, R., \& Salazar, N. (1999). Interest spreads in banking in Colombia, 1974-96. IMF staff papers, 46(2), 196-224.

[4]. Barajas, A., Steiner, R., \& Salazar, N. (2000). The impact of liberalization and foreign investment in Colombia's financial sector. Journal of development economics, 63(1), 157-196.

[5]. Brock, P. L., \& Suarez, L. R. (2000). Understanding the behavior of bank spreads in Latin America. Journal of development Economics, 63(1), 113-134.

[6]. Choate, G. M., \& Archer, S. H. (1975). Irving Fisher, Inflation, and the Nominal Rate of Interest. Journal of Financial and Quantitative Analysis, 675-685.

[7]. Fisher, I. (1930). Theory of interest: as determined by impatience to spend income and opportunity to invest it. Augustusm Kelly Publishers, Clifton.

[8]. Fofack, A. D. (2016). The determinants of interest rate spread: Empirical evidence from the Central African economic and monetary community. Journal of Economics and International Finance, 8(6), 66-78.

[9]. Gambacorta, L. (2008). How do banks set interest rates?. European Economic Review, 52(5), 792-819. https://doi.org/10.1016/j.euroecorev.2007.06.022

[10]. Ganić, M. (2018). An empirical analysis of factors affecting bank interest margins: Evidence from the South East European countries. Comparative Economic Research, 21(2), 81-98.

[11]. Raharjo, P. G., Hakim, D. B., Manurung, A. H., \& Maulana, T. N. (2014). The determinant of commercial banks' interest margin in Indonesia: An analysis of fixed effect panel regression. International Journal of Economics and Financial Issues, 4(2), 295.

[12]. Randall, M. R. (1998). Interest rate spreads in the Eastern Caribbean. International Monetary Fund.

[13]. Samahiya, M., \& Kaakunga, E. (2014). Determinants of Commercial Banks' Interest Rate Spread in Namibia: An Econometric Exploration. Botswana Journal of Economics, 12(1), 1-10.

[14]. Saunders, A., \& Schumacher, L. (2000). The determinants of bank interest rate margins: an international study. Journal of international Money and Finance, 19(6), 813-832.

[15]. Smirlock, M. (1985). Evidence on the (non) relationship between concentration and profitability in banking. Journal of money, credit and Banking, 17(1), 69-83.

[16]. Were, M., \& Wambua, J. (2014). What factors drive interest rate spread of commercial banks? Empirical evidence from Kenya. Review of development Finance, 4(2), 73-82. 